\title{
AN INTERPRETATION OF CUEVA DE LA HUACHIZCA, SANTA CLARA DEL COBRE, MICHOACÁN, MÉXICO
}

\author{
Cinthia Marlene Campos ${ }^{1, C}$, José Luis Punzo-Díaz², Veronica Lopez Delgado ${ }^{3}$, Avto Goguitchaichvili \\ and Juan Morales ${ }^{3}$
}

\begin{abstract}
Cueva de la Huachizca is located in the humid forests of the Municipio of Santa Clara del Cobre, Michoacán. During the Postclassic period (1300-1520 AD), Santa Clara del Cobre was a part of the Tarascan Señorio. Ethnographic accounts describe the use of Cueva de la Huachizca as a place of refuge during the Cristero Rebellion (1921-1926). Recent investigations suggest a long history of use including graffiti and inscriptions from the 1800s-1900s and a rock art panel. The panel consists of pecked petroglyphs depicting a man facing an eagle, above a spiral motif. Stylistic analysis of the panel suggests that the rock art was created during pre-Hispanic times, likely by the Postclassic Tarascans. As observed in several regions of Mesoamerica, for the Tarascans, caves were also liminal spaces and had an important role in Postclassic Tarascan cosmology. A ceramic resinera, a pine resin pot, an eagle's feather, and charcoal were also recovered. The resinera age was estimated by researchers at Archaeomagnetic Services, Geophysics Institute at the National Autonomous University of México-Campus Morelia, Michoacán to between 1921 and 1980. Ethnographic and ethnohistoric accounts describe caves as houses of fertility and rain deities, an idea that while slightly transformed, has survived over 500 years of colonization, and remains in the communities' social memories. These findings demonstrate the cave's significance among the descendent communities and Cueva de la Huachizca as an important sacred site.
\end{abstract}

\section{INTRODUCTION}

Cueva de la Huachizca is located in the humid forests of the municipio, Santa Clara del Cobre near the archaeological sites Itziparátzico and Pátzcuaro. During the Postclassic period (1300-1520 AD), Itziparátzico was part of the Tarascan Señorio. The Señorio was divided into three capitals, Ihuatzio, Pátzcuaro, and Tzintzuntzan. At the time of contact, Tzintzuntzan was the main politico-religious center, from which the Calzonci, or supreme ruler, controlled a multi-ethnic empire spanning over 75,000 square kilometers including Itziparátzico (Alcalá, 2013; Pollard, 2008; Punzo-

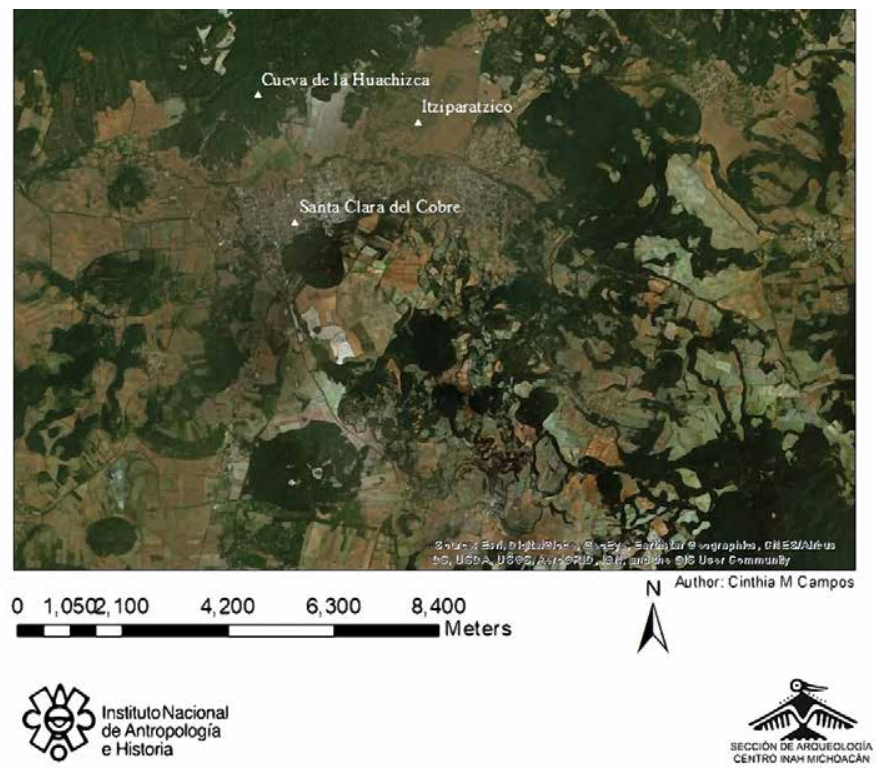

Figure 1. Cueva de la Huachizca, located in the forests of Salvador Escalante, Michoacán, México. The map shows the cave in relation to the Postclassic Tarascan site of Itziparatzico and the colonial town of Santa Clara del Cobre. Díaz, 2014) (Fig. 1). The Señorio consisted of a series of tributary city-states united by the Uacúsecha or Eagle's Men lineage, (Alcalá, 2013; Pollard, 2008). Santa Clara del Cobre belonged to Itziparátzico, one of the largest and most important metalsmithing towns (Alcalá, 2013; Maldonado and Rehen, 2009; Punzo-Díaz, 2014).

The name "Cueva de la Huachizca" comes from the word huaches, or Indian, which suggests that the cave was primarily utilized by the Indigenous population (Warren, 1990). According to informants from Santa Clara del Cobre, the cave has been known for centuries and remains a part of the communities' social memory. According to informants, the cave served as a refuge during the Mexican Revolution and Cristero Rebellion (1921-1926). The cave was first scientifically recorded in 2014 by Proyecto Arqueologia y Paisaje del Area Centro-Sur de Michoacán (PAPACSUM), directed by José Luis Punzo-Díaz (Punzo-Díaz et al., 2015). Their report (Punzo-Díaz et al., 2015) suggests that the cave is small, composed of a single chamber. The cave was visited again in 2016 by Cinthia M. Campos and Alejandro Valdes-Herrera as part of the Tarascan Caves Reconnaissance, a sub-project of PAPACSUM 2016-2017 (Campos, 2018). This survey found

\footnotetext{
${ }_{1}^{1}$ Anthropology, Binghamton University, State University of New York, 4400 Vestal Parkway East Binghamton, NY 13902-6000 United States ${ }_{2}^{2}$ Arqueología, Instituto Nacional de Antropología e Historia- Morelia, Francisco I. Madero Oriente 799 Col. Centro C.P. 58000 Morelia, Michoacán, México

${ }^{3}$ Servicio Arqueomagnético Nacional, Instituto de Geofísica- Universidad Nacional Autónoma de México- Morelia, Michoacán

c Corresponding Author: cmcampos13@outlook.com
} 
a passage heading northward from the known chamber that eventually led to a second, partially blocked entrance. In total, $109 \mathrm{~m}$ of passage were mapped, making this one of the longest caves in the area.

\section{CUEVA DE LA HUACHIZCA}

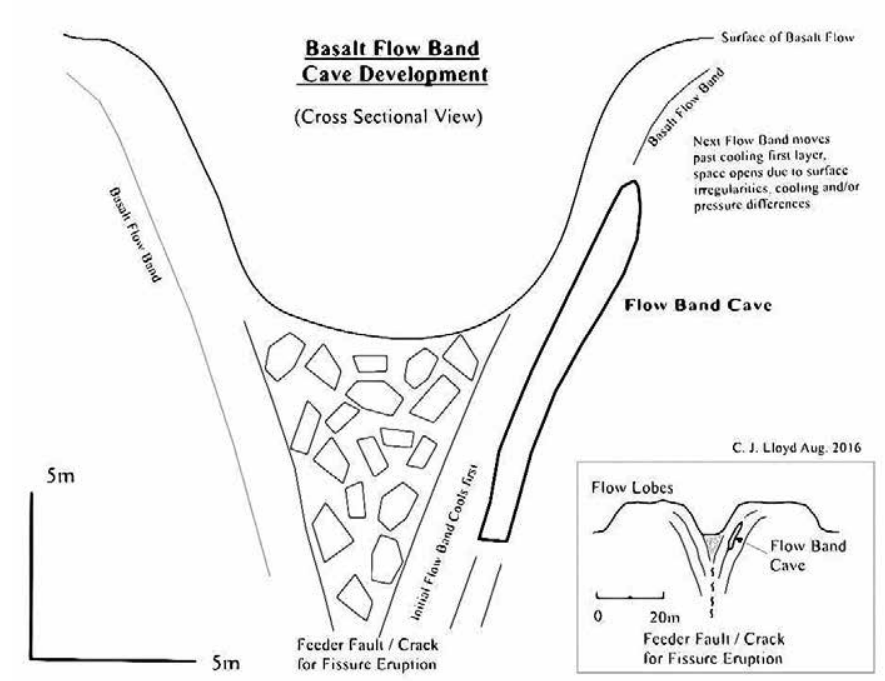

Figure 2. A cross section view of the formation of the cave. (Lloyd, 2016).

This area of Michoacán is part of the Trans-Mexican Volcanic Belt, and therefore, non-karstic. Geologist Christopher Lloyd (2016) proposes that Cueva de la Huachizca is a flow-band basalt cave (Fig. 2). Flow bands can occur during laminar lava flows if there are differing viscosities in the lava thus segregating the laminar lava flows. Lava draining from a lower flow band leaves an accretionary band above with an open space between the bands as lava drains when the flow ceases from the eruption.

Cueva de la Huachizca (Fig. 3) consists of a single long rift passage oriented north-south that drops some $18 \mathrm{~m}$ over its length. The southern or main cave entrance is obscured by large breakdown and measures $3.5 \mathrm{~m}$ in width by $2 \mathrm{~m}$ in height. Just inside the southern entrance, the cave becomes multi-leveled with a lower passage paralleling the upper passage. The lower passage was deemed unsafe and was not further explored.

In June 2016, the cave was surveyed and mapped. This cave was particularly difficult to map because it is filled with loose sharp basalt breakdown and requires

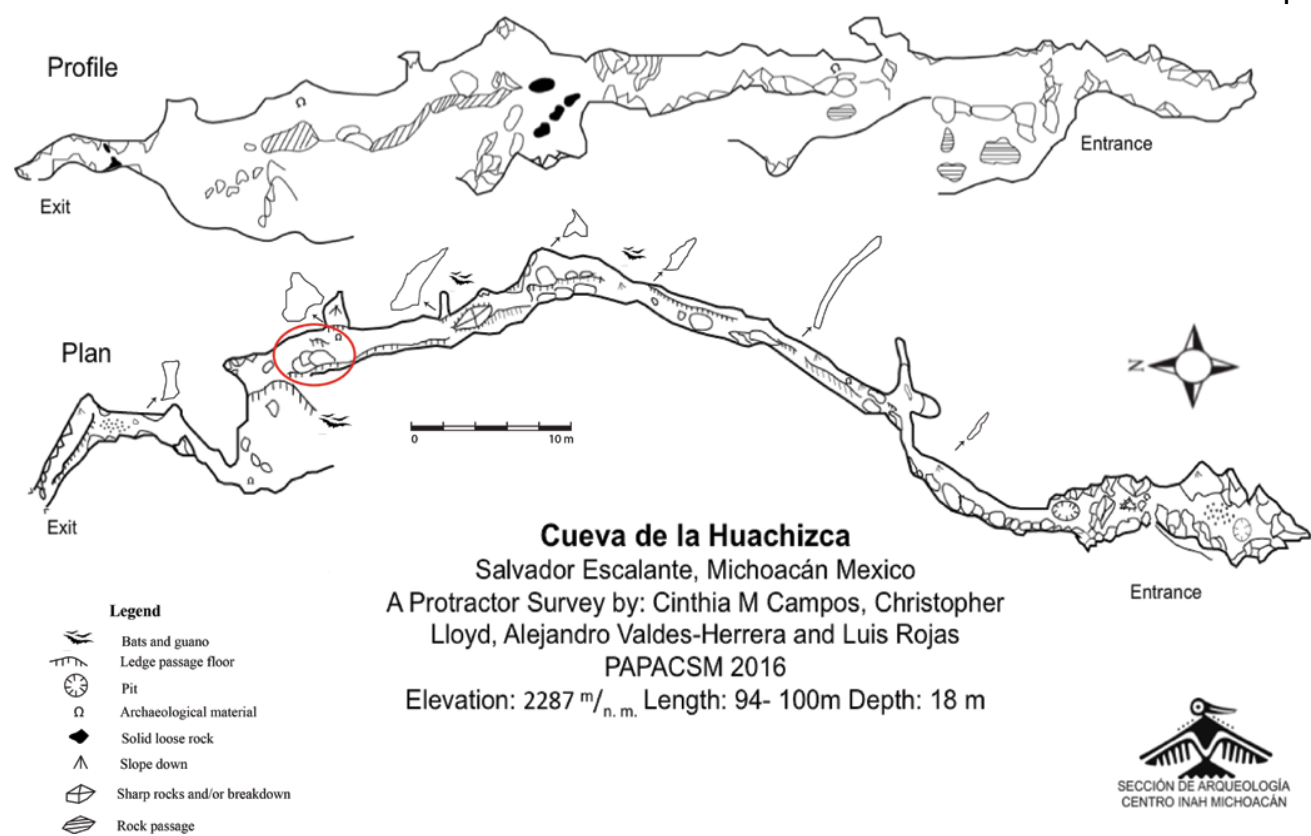

Figure 3. The plan view and profile maps of Cueva de la Huachizca showing the dimensions and complexity of the cave. The location of the rock art panel and the feather is circled in the plan view map. some climbing skills. Due to the complexity of the cave, two experienced cavers from Guadalajara assisted, Christopher Lloyd and Luis Rojas. Despite its relatively small size, it took three days to survey and map the cave. The first survey was conducted with a tandem SUUNTO compass and clinometer. The strong magnetic force inside the cave interfered greatly with azimuth readings, forcing us to restart the survey using a protractor and two small handheld laser pointers. As part of the surface survey, artifacts were photographed, recorded, and collected for further lab analysis. A third visit was dedicated to recording, photographing, and tracing the rock art panel.

The presence of graffiti attest to the cave's historical use. The eastern and western walls of the southern entrance contain multiple etchings of names and dates of individuals who visited the cave during the late 1800 s and early 1900 s. A Spanish-style cross measuring $10 \mathrm{~cm}$ in height by $6 \mathrm{~cm}$ in width is incised in the basalt on the north-facing wall. Carved onto that same panel, just below the cross, is the year 1996. The eastern and western walls of the southern entrance contain multiple etchings of names and visiting dates of cave visitors during the late 1800 s and early 1900s. Less graffiti is found at the north entrance and completely absent beyond $50 \mathrm{~m}$ north of the south entrance

South of the main entrance is a spacious chamber measuring $9.5 \mathrm{~m}$ long by $3.5 \mathrm{~m}$ wide and $3 \mathrm{~m}$ at its highest point. Inside the southern chamber, the walls consist of basalt breakdown through which little to no light enters. A looter's pit 
was found in the southeastern corner of the chamber, seven meters south of the entrance. The looter's pit is circular in shape and measures $75 \mathrm{~cm}$ in diameter and ranges between $5 \mathrm{~cm}$ and $10 \mathrm{~cm}$ in depth. The pit contained an accumulation of soil and breakdown at its base suggesting that it was dug in antiquity. No artifacts were found in the pit nor in the southern part of the cave.

As the cave lacks skylights, all artifacts documented in the cave were found in the dark zone. At 17 meters north of the south entrance, the first artifact was identified, a partially broken ceramic resinera, a pine resin pot, which functioned as a resin lamp when ignited. Resineras were used from colonial times into the historic period. The resinera measures $17 \mathrm{~cm}$ in height, $20 \mathrm{~cm}$ in diameter, and $2-3 \mathrm{~cm}$ in thickness. It was lodged between two basalt slabs approximately three meters below the walking passage. The resinera was found upright, in a section where the sloping basalt walls narrow sharply. Had the resinera been smaller in diameter, it would have slipped down into the lower passage which is physically inaccessible. The resinera was filled with charred pine resin and small organic fibers possibly used as kindling. The cave's conditions and location of the ceramic lamp allowed for the excellent preservation of the lamp and its contents.

\section{THE ROCK ART PANEL AND ASSOCIATED ARTIFACTS}
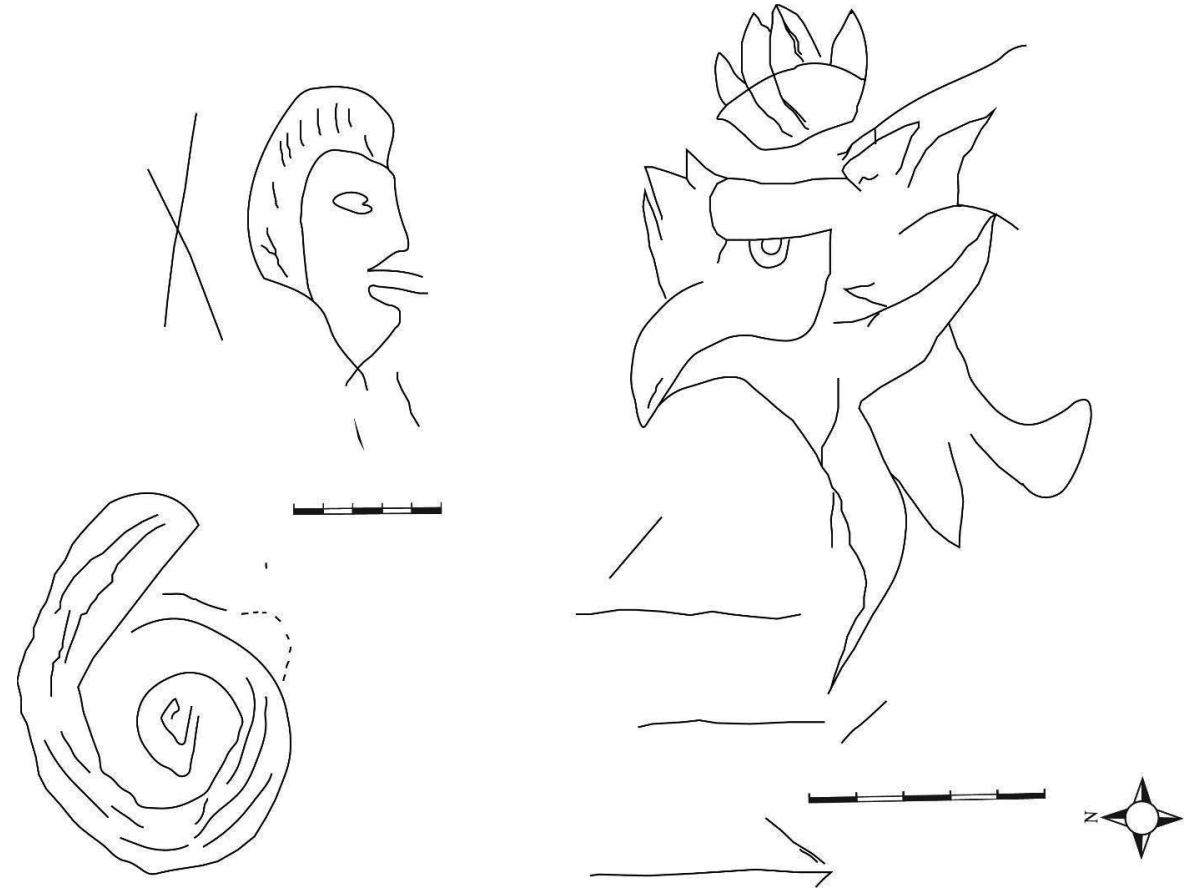

Figure 4. The rock art panel at Cueva de la Huachizca depicting a man facing an eagle above an inward spiral motif and an arrow pointing in the southern direction.
At $63.52 \mathrm{~m}$ north of the southern entrance, a rock art panel was incised on the east wall (Fig. 4). The panel is etched on a flat section of basalt, clear of lava stalactites. It is noteworthy because the passage opens to a height of $3.5 \mathrm{~m}$, with a full meter of walking surface, as opposed to the narrow sloping $0.5 \mathrm{~m}$ wide passages found in much of the rest of the cave. At its highest point, the rock art panel is located $1.60 \mathrm{~m}$ above the floor, at eye level for an individual of short to medium stature

The panel, $2.15 \mathrm{~m}$ in length and $1 \mathrm{~m}$ in height, consists of four motifs. A clearly defined spiral motif is located in the lower north-west quadrant of the panel; the motif is similar to those recorded at Tzintzuntzan (Gómez-Mussenth, 2010; Olmos, 2010). At the spiral glyph's level is a line and an arrow pointing south towards the entrance. Above and east of the spiral is an image of a man's head with clearly defined hair combed back and his mouth open. Two thin lines are noted emerging out of the man's mouth. The man is facing southward and is at the same level as an eagle's head, which is significantly larger than the man. The eagle motif is facing in a northward direction, looking directly at the man. Tracing of the rock art panel revealed a crown motif above the eagle's head that was not visible in photographs. The crown is not as deeply incised as the other images; it is very thin and faint compared to the man, spiral, and eagle that appeared to be traced over multiple times. This leads us to believe it may have been added later in time and perhaps using different tools.

On a ledge in the western wall $1.5 \mathrm{~m}$ above the floor and across from the rock art panel, a single feather was found. The feather, $27.5 \mathrm{~cm}$ long by $6 \mathrm{~cm}$ wide, is weathered yet maintains its size and color (Fig. 5). Biologist Dr. Jorge Schöndube, at the National Autonomous University of Mexico (UNAM)-Morelia, identified the feather as a primary feather. Its size, coloration, and features indicate that it may have belonged to an Aquila chrysaetos, widely known as a golden eagle (Schöndube, personal communication 2016). Magnified images of the feather show that its calamus, or the hollow point, is intact, suggesting that the feather was not brought in by an animal. The feather's integrity and context suggest that it was deliberately placed in front of the rock art panel, perhaps as an offering. The feather was found in association with three small pieces of charcoal further confirming human activity. The passage floor below the rock art panel was littered with burnt wood and charcoal. More evidence of burning was found approaching the north entrance, including black soot on the roof of the cave and small fragments of burned wood. 


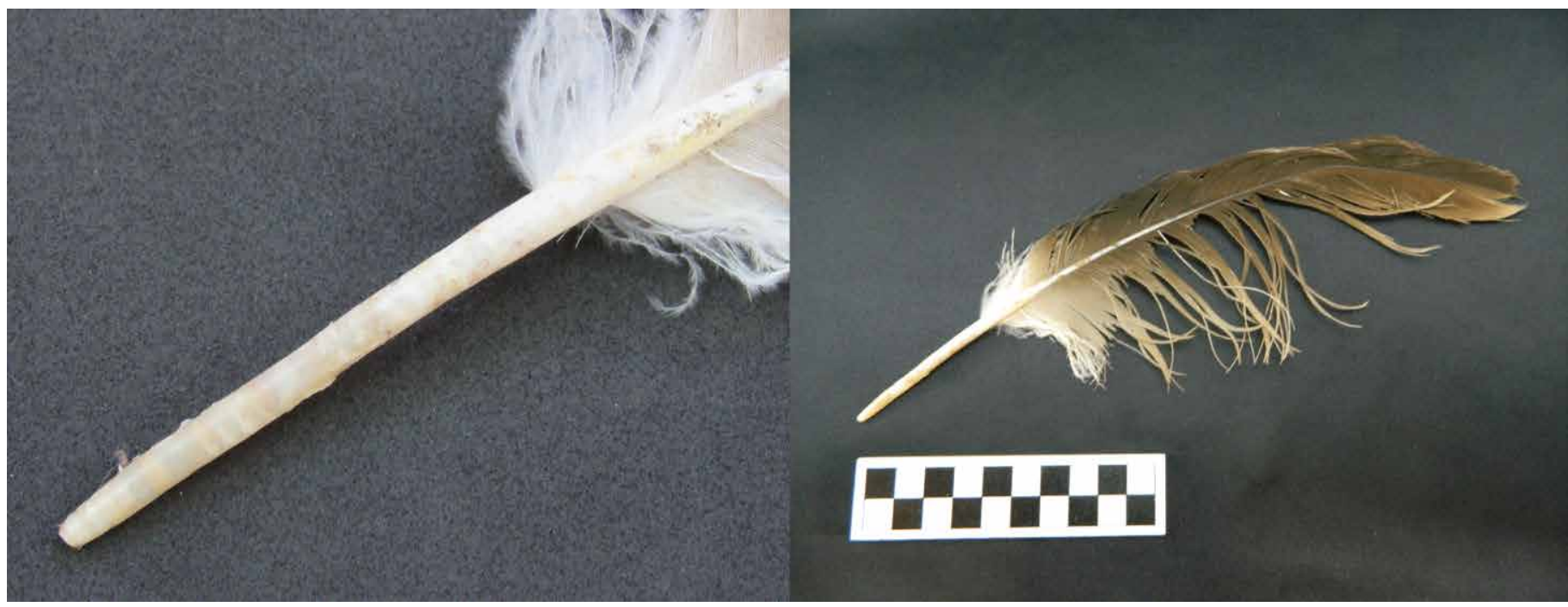

Figure 5. The feather found on a ledge across the rock art panel (right) and its calamus (left). Despite some weathering along the hollow shaft and barbs, the feather is free of sediment, rodent, and bill marks.

\section{RESULTS OF ARCHAEOMAGNETIC DATING}

The resinera was analyzed using archaeomagnetic techniques at the facilities of the National Archaeomagnetic Service at UNAM- Morelia. Absolute archaeointensity measurements were performed using the Thellier double heating

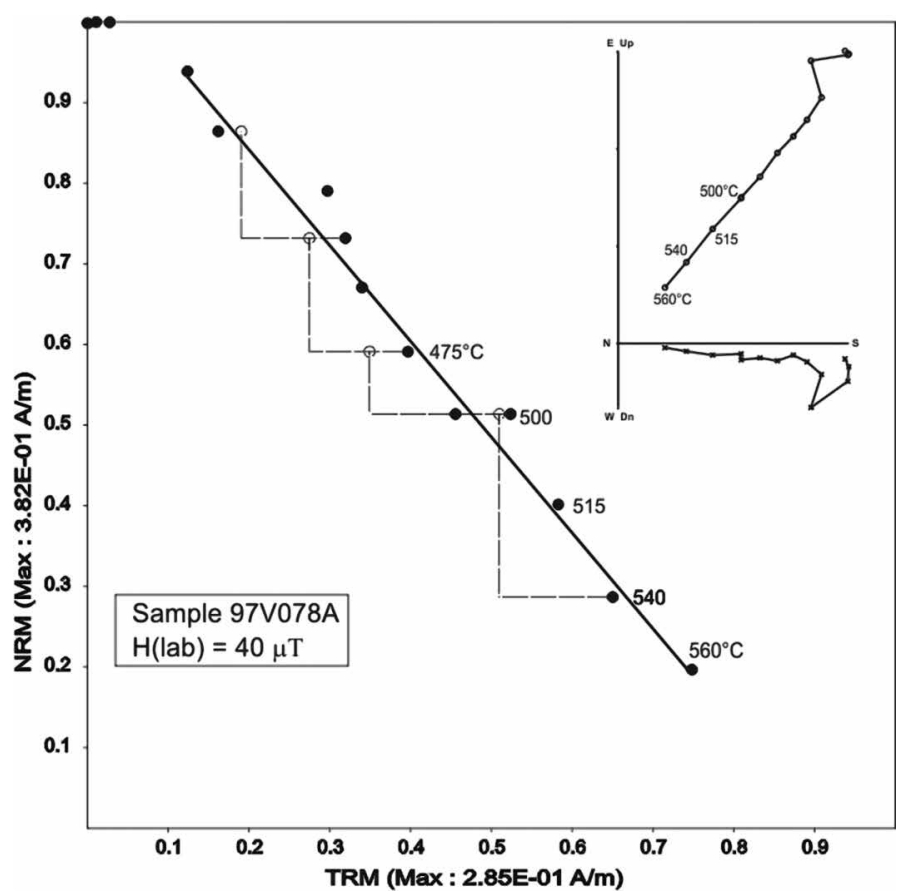

Figure 6. Representative Natural Remanent Magnetization (NRM)-Thermomagnetic Remanent Magnetization (TRM) plots, also known as Arai-Nagata plot and associated Zijderveld demagnetization diagrams for the representative samples. method (Thellier and Thellier 1959) as modified by Coe et al. (1978). An ASC TD-48 single chamber demagnetizer equipped with the coils to produce magnetic fields and an AGICO JR6-A spinner magnetometer were used for the analysis. A fragment of the resinera was broken into 6 samples and pressed into salt pellets to facilitate their treatment as standard paleomagnetic samples. Intensity determination (Fig. 6) was carried out in 14 temperature steps, between room temperature and $560{ }^{\circ} \mathrm{C}$. Temperature reproducibility between two heatings to the same temperature was less than $2{ }^{\circ} \mathrm{C}$ and laboratory field intensity was set to $40 \mu \mathrm{T}$ and held with a precision better than 0.1 $\mu \mathrm{T}$. During the experiment, several control heatings, socalled pTRM-checks, were carried out. The cooling rate dependence of TRM (Thermoremanent Magnetization) was investigated following a modified procedure described by Chauvin et al. (2000). At the end of experiments, all specimens were heated three more times at $560{ }^{\circ} \mathrm{C}$, to create three consecutive TRMs under the same laboratory field. The three consecutive TRMs were performed at different laboratory assisted speeds, fast, slow, fast. To minimize the anisotropy effect of TRM, each fragment was divided into at least six specimens and embedded in salt pellets in six positions $( \pm X, \pm Y, \pm Z)$ relative to a priori selected direction of the sample. The magnetic field was then applied along the $+Z$ direction. In this way, anisotropy effects were canceled out or at least minimized as showed by Morales et al. (2015).

All six analyzed specimens yielded technically acceptable determinations (Table 1). For these samples, the NRM fraction $f$ used for determination ranges between 0.69 and 0.75 , while the quality factor $q$ ranges from 5.7 to 17.5 (Table 1). The individual archaeointensity values obtained in this study range from $39.14 \mu \mathrm{T}$ to $49.45 \mu \mathrm{T}$ with a fragment mean value of $44.78 \mu \mathrm{T}$. The results of archaeomagnetic dating (Fig. 7) using the last model SHADIF14K of Pavón-Carrasco et al. $(2011,2014)$ combined with data retrieved from the Teoloyacan geomagnetic observatory (Hernández-Quintero et 
Table 1. Archaeointensity results obtained from the resinera specimens.

\begin{tabular}{ccccccccc}
\hline Sample & Lab Code & $\boldsymbol{n}$ & $\boldsymbol{T}_{\min }-\boldsymbol{T}_{\max }\left({ }^{\circ} \mathbf{C}\right)$ & $\boldsymbol{f}$ & $\boldsymbol{g}$ & $\boldsymbol{q}$ & $\begin{array}{c}\boldsymbol{B}(\boldsymbol{\mu} \boldsymbol{T}) \\
\text { Corrected }\end{array}$ & $\boldsymbol{\sigma} \boldsymbol{B}(\boldsymbol{\mu} \mathbf{T})$ \\
\hline SCC1a & $97 \mathrm{~V} 073 \mathrm{~A}$ & 11 & $200-560$ & 0.81 & 0.89 & 17.5 & 45.59 & 1.4 \\
SCC1b & $97 \mathrm{~V} 074 \mathrm{~A}$ & 10 & $250-560$ & 0.81 & 0.88 & 12.8 & 46.57 & 1.2 \\
SCC1c & 97V075A & 9 & $250-540$ & 0.75 & 0.79 & 5.7 & 39.14 & 1.6 \\
SCC1d & $97 \mathrm{~V} 076 \mathrm{~A}$ & 10 & $250-560$ & 0.77 & 0.82 & 13.6 & 42.39 & 1.1 \\
SCC1e & 97V077A & 9 & $250-540$ & 0.79 & 0.78 & 6.6 & 49.44 & 2.1 \\
SCC1f & 97V078A & 11 & $200-560$ & 0.78 & 0.87 & 18.1 & 45.54 & 1.2
\end{tabular}

$T_{\min }-T_{\max }=$ the temperature interval involved for intensity determination.

$n=$ the number of heating steps used for the intensity determination.

$f=$ the fraction of NRM used for intensity determination.

$g=$ the gap factor.

$q=$ the quality factor as defined by Coe et al. (1978).

$B_{\text {corr }}=$ archeointensity value corrected for cooling rate effect.
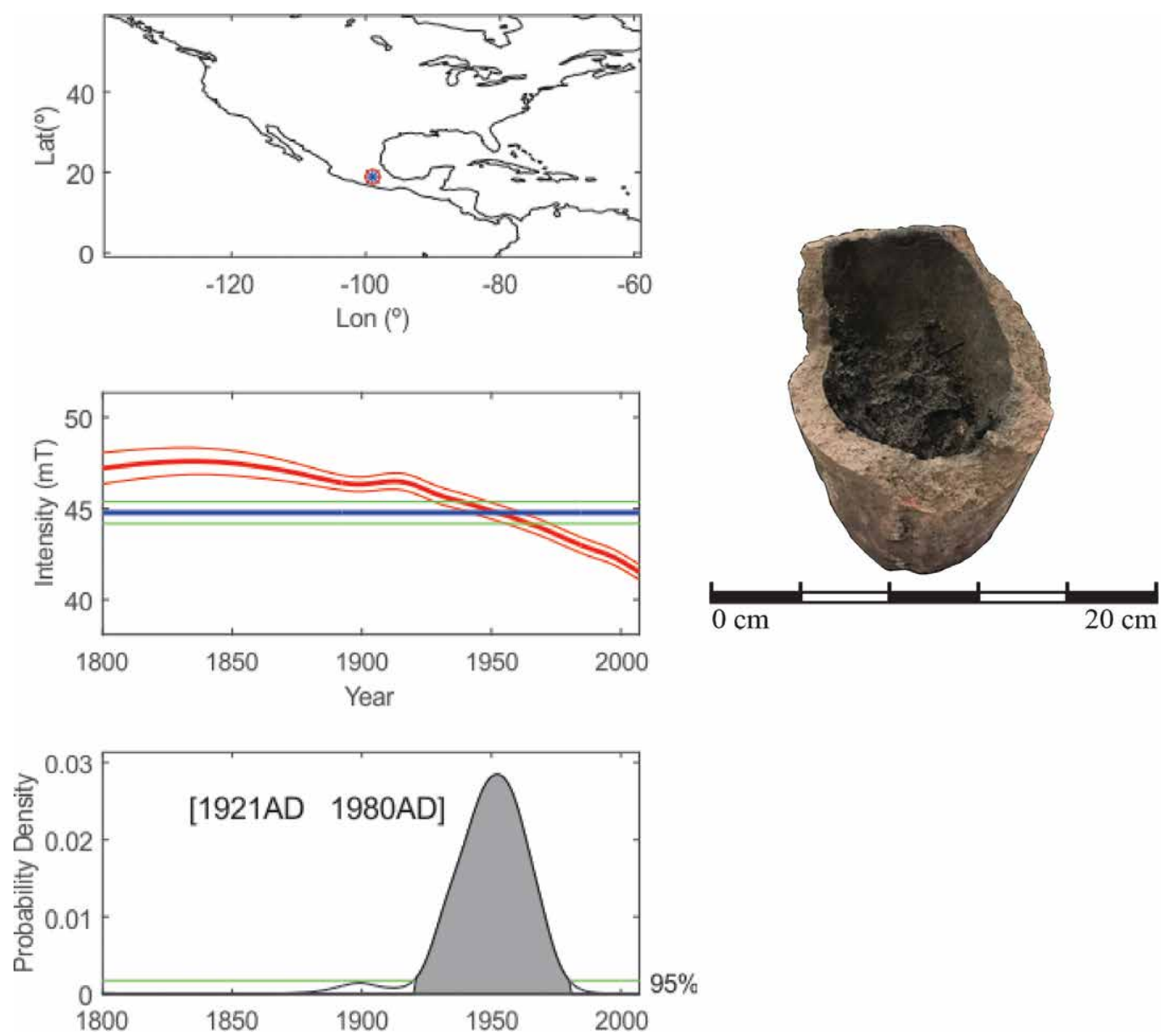

Figure 7. Archaeomagnetic dating of the resinera samples using a MATLAB tools provided by Pavón-Carrasco et al. $(2011,2014)$ using SHA14Kdif model combined with observatory data for the last 100 years.

site for the ancient Tarascans.

Today, the cave is protected as part of the Ejido Salvador Escalante and remains under the protection of the local Indigenous community. According to local Purépecha speakers, to them "any opening into the earth" is considered a cave (Warren, 1990). The association of caves as sacred spaces is further supported by Carrasco's (1952) ethnographic studies among the Purépecha communities and Punzo-Diaz's (2018) interpretation of the Relación sobre la Resistencia de Michoacán (Pátzcuaro) (Ramírez, 1959). Therefore, in a non-karst volcanic region, where caves seldomly form, a cave of this size is certainly noteworthy. al., 2018) yielded a time interval between 1921 and 1980 as the best estimate of the resinera recovered at Cueva de la Huachizca.

\section{DISCUSSION}

As mentioned, the cave is located in Santa Clara del Cobre, which in pre-Hispanic times was part of the ancient town of Itziparátzico. This archaeological site consists of differentiated habitation areas, a wide variety of ceramic and lithic artifacts, 30 small mounds, and a large yacata (Punzo-Díaz, 2014) confirming Tarascan presence. In pre-Hispanic times Itziparátzico was an important site as it connected the copper mines in the Tierra Caliente region to the Lake Pátzcuaro Basin, where the socio-political leaders of the Tarascans resided. Metals played a significant role in agency and power in pre-Colombian times and their use was limited to the politico-religious elite. According to Relación de Michoacán, metals were considered to be the excrement of the gods. Silver was associated with Xaratanga, the Tarascan water and moon goddess, while gold and copper were associated with Curicaueri, the Tarascan fire and solar deity (Alcalá, 2013; Pollard, 1993, 2008; Roskamp, 2005, 2010a). Therefore, as a copper manufacturing site, Itziparátzico was an important socio-political 
The feather is significant as it suggests that locals continue to visit the cave. As described in the Relación de Michoacan, both wood and feathers, particularly those of predatory birds, were often presented as ceremonial offerings to the solar deity, Curicaueri (Alcalá, 2013). Interestingly, results from radiocarbon analysis conducted on the charcoal remains recovered at the base of the rock art panel indicated that the samples were post-1950, suggesting continued visits through the $19^{\text {th }}$ and 20th centuries. The archaeomagnetic analysis suggest that the resinera was likely dropped between 1921 and 1980 which is contemporaneous to the Cristero Rebellion (1921-1926) confirming the community's ethnographic and historical accounts. As a result, we cannot ascertain whether the feather and charcoal were introduced at the same time or by the same individuals. However, it is clear that the artifacts found are not all contemporaneous. This is significant as it links to the pre-Hispanic and colonial past until modern-day, suggesting that the cave remains an important and sacred site to the community.

The rock art found within the cave differs from rock art recorded elsewhere in Michoacán, which often consists of anthropomorphic creatures, geometric designs, handprints, and figures (Gómez-Mussenth, 2010; Olmos, 2010). The rock art resembles images drawn by Indigenous informants in Codice Plancarte, Codice de Huetamo, and the Lienzo de

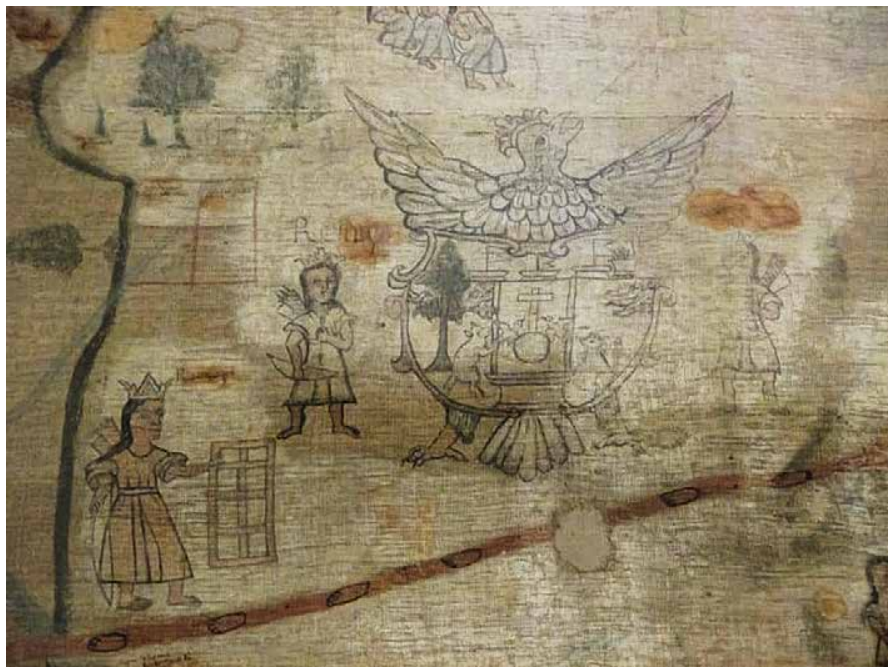

Figure 8. Contact period illustrations of Tarascan nobles, Acús Thicátame as depicted in the Codice de Carapan. Curicaueri, the Tarascan solar and fire deity, is represented as an eagle wearing a Spanish-style crown (Corona-Núñez, 1986). Jujucato or Jicalan (Corona-Núñez, 1986, Roskamp 2005, 2010b) (Fig. 8). This would suggest that the rock art panel was carved during the Late Postclassic or the colonial period. The continuous occupation of Indigenous Purépecha in the region along with the particular iconographic symbols and stylistic form, suggest that the ancient Tarascans are the creators of the rock art panel. As noted, the manufacture of the petroglyphs was not uniform. The lines of the crown above the eagle are much thinner, finer, and shallower. The difference between these lines and the rest of the panel is so stark, suggesting the crown was added later and perhaps with different tools.

This is not to say, however, that the crown is unimportant. We would suggest that a later visit to the cave added the crown above the eagle to update and give a Spanish translation to the eagle motif. Interestingly, the eagle is an early motif associated with rulership in Mesoamerica. Grove (1973) has shown that Olmec sculptures referred to as "altars" are actually thrones. La Venta Altar 4 depicts an individual emerging from a niche in the throne that iconographically represents a cave. The individual wears a headdress in the form of an eagle. The identification of the sculpture as a throne was based on a painting at Oxtotitlan Cave in Guerrero that depicts a man seated on a throne with the same jaguar iconography as La Venta Altar 4. The man on the throne is shown wearing an eagle costume. Thus, the connection between caves, eagles, and rulership dates back to at least $1000 \mathrm{BC}$.

Anthropologists have emphasized an important class of rituals called "rites of passage" (Brady and Prufer, 2005; Heyden 1975, 2005). Van Gennep (1960) defined rites of passage as ceremonies that marked transitions in social status, age, and/or space or location. He noted that these rites of passage followed a common script in which the individual entered a liminal space where the ceremony was performed and then re-entered a normal space with his/her new status. Liminal space needs to be isolated and distinctively different from "normal" space, making caves ideal liminal spaces. All individuals experience several rites of passage throughout their lives, such as birth, puberty, marriage, and death. Doris Heyden $(1975,2005)$ stated that caves were frequently the settings for rites of passage, particularly involving the accession to rulership.

The rite of passage is well documented in the Aztec accession ritual. The tlatoani spent the night before taking office in the temple of Yopico praying and bloodletting. The temple was a symbolic cave with a hole in the floor called oztoc, "cave" (Townsend, 1987). A similar rite of passage is described in Fray Jeronimo de Alcalá's Relación de Michoacán (Alcalá, 2013). According to narratives, Tariacuri, the Calzonci renowned for uniting and forming the Tarascan Señorio, ordered his son and nephews, Hiquingaje, Hirípan and Tangaxoan, respectively, to perform auto-sacrifice in a cave (Alcalá, 2013). Lamina 16 (Alcalá, 2013) shows three young men sitting around a fire in a cave with their ears swollen and bleeding after performing auto-sacrifice (Fig. 9). Upon their return from the cave, Tariacuri made them Señores and assigned each a part of his estate, creating the three Tarascan capitals, Pátzcuaro, Ihuatzio, and Tzintzuntzan. 


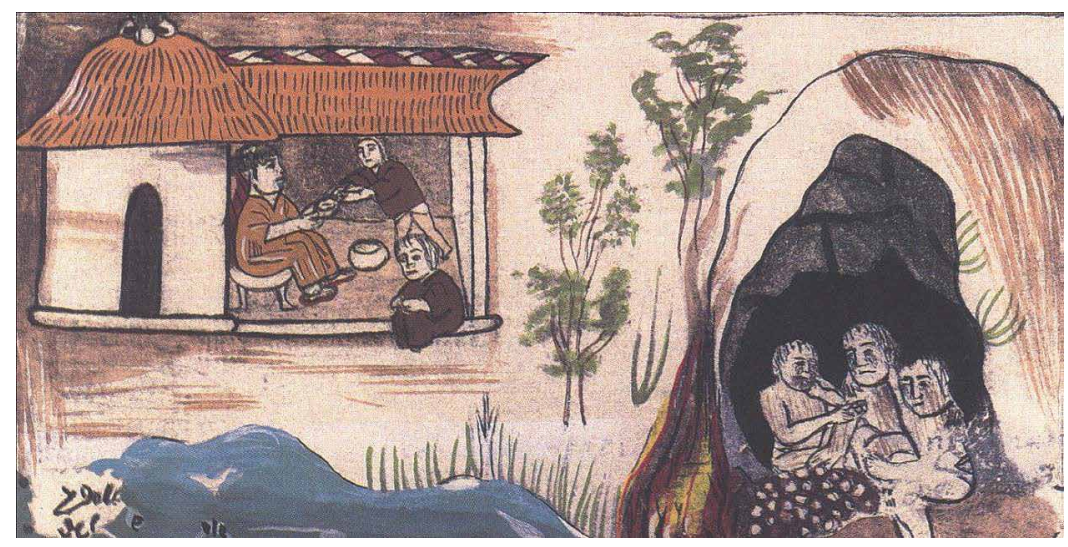

Figure 9. Lamina 16 in La Relación de Michoacán showing the three young men performing auto-sacrifice inside a cave across Lake Patzcuaro (Alcalá, 2013).

The association between caves, eagles, and rulership remained prominent even after the Spanish conquest (Castañeda de la Paz and Roskamp, 2013; Roskamp, 2005, 2010a, 2010b). Illustrated in the top left corner in the City of Tzintzuntzan's 1593 coat of arms is a cave formed by seven stacked rocks across a body of water. Adjacent to this is an image of an island in the middle of the lake, representing the Isle of Janitzio in the center of Lake Pátzcuaro. According to Roskamp (2010b), the cave is symbolic of the creation story describing the Chichimecs exit from the seven caves of the west, or Chicomoztoc, and their migration to the Lake Pátzcuaro basin (De la Rea and Escandón, 1996). The coat of arms is located in the center of the body of a Golden Eagle and raised by Harame and Hireti Thicatame, two Uacúsecha Señores descendants of Tariacuri. The illustration confirms narratives describing how authority was limited to Uacúsecha males and shows eagles and caves as symbols of power (Alcalá, 2013, González-Martínez, 2010, Roskamp, 2005, 2010a, 2010b). This is further supported by the contact period Tarascan Codice de Carapan, in which the eagle holding up the coat of arms is also depicted wearing a crown (see Fig. 8). Thus, it is not coincidental that the crown over the eagle at Cueva de la Huachizca would be etched at a later time. The artistic similarities between the Codice de Carapan and the images found on the basalt within Cueva de la Huachizca suggest that the Tarascan nobles from Itziparátzico carved the rock art panel. Drawing on Sandra Cruz Rivera's (2019) analysis of pre-Hispanic codices, the two thin lines coming out of the man's mouth suggest that the individual is emitting sounds or speech directed at the eagle. Thereby, suggesting that the panel depicts a ritual performed in the Cueva de la Huachizca that involved an act of communication between the man and the eagle (Cruz Rivera, 2019).

\section{CONCLUSIONS}

This article presents the results of an archaeological survey conducted by PAPACSUM of previously unpublished Cueva de la Huachizca. This study paid particular attention to the rock art panel that stylistically appears to date to the Postclassic Tarascans. The eagle motif and the cave are shown to be associated with rulership from the earliest Mesoamerican iconography. The crown above the eagle motif appears to be a post-conquest addition that confirms our interpretation. We suggest that the panel within the cave indicates that Cueva de la Huachizca may have been used as one part of rituals of passage in the accession of rulers of the nearby site of Itziparátzico. This would make sense since the cave is one of the longest in the area (Rissolo, 2001).

Our survey has documented a long history of the use of Cueva de la Huachizca with graffiti recording visitation during the late nineteenth and early twentieth centuries. The dates suggest cave utilization during or after the Mexican Revolution. Archaeomagnetic dating of the resinera to the twentieth century is significant because the range overlaps with the Cristero Rebellion, confirming the stories described by informants that the cave was a refuge for indigenous communities. Finally, it is important to note that Cueva de la Huachizca is a very important and sacred landscape marker for the community members of Santa Clara del Cobre.

\section{ACKNOWLEDGMENTS}

We would like to extend our gratitude to the community members of the Huatápera at Santa Clara del Cobre for welcoming us and providing access to the site. Thank you to Dr. Jasinto Robles, Alejandro Valdes-Herrera, and Lissandra Gonzalez-Gonzalez at the Instituto Nacional de Antropología e Historia in Morelia. We also wish to thank geologist Christopher Lloyd and speleologist Luis Rojas for their assistance during the cave survey. Thank you to biologist Jorge Schöndube and geophysicists Avto Gogichaistvili, Veronica Lopez Delgado, and Juan Morales from the National Autonomous University of Mexico (UNAM) of Morelia, Mexico for help with artifact analysis. Special thanks go to James E. Brady, Allan Cobb and several anonymous reviewers for their comments and suggestions which helped strengthen this manuscript. This research in sacred geography and the use of caves in Michoacán was supported by the Archaeological Institute of America and the National Speleological Society's Ralph W. Stone Graduate Fellowship.

\section{REFERENCES}

Alcalá, F.J., 2013, Relación de las ceremonias y ritos y población y gobernación de los indios de la provincia de Michoacán (1539-1541), [Relación de Michoacán]: Zamora, Michoacán: Colegio de Michoacán, Gobierno del Estado de Michoacán. 
Brady, J.E., and Prufer, K., eds., 2005, In the Maw of the Earth Monster: Mesoamerican Ritual Cave Use: University of Texas Press, Austin. https://doi.org/10.1111/j.1467-9655.2006.00303_1.x

Campos, C.M., 2018, Exploring Ancient Tarascan Ritual Cave Use in Central-Southern Michoacán, Mexico. [Master's thesis]: California State University, Los Angeles.

Carrasco, P., 1952, Tarascan Folk Religion: An Analysis of Economic, Social, and Religious Interactions, Preprinted from Publication 17, Middle American Research Institute: The Tulane University of Louisiana, New Orleans, p. 1-64.

Castañeda de la Paz, S., and Roskamp, H., eds., 2013, Los escudos de armas indígenas: de la Colonia al México Independiente. Instituto de Investigaciones Antropológicas, Universidad Nacional Autonóma de México, Ciudad de México y El Colegio de Michoacán: Zamora, Michoacán.

Chauvin, A., Garcia, Y., Lanos, P., and Laubenheimer, F., 2000, Paleointensity of the geomagnetic field recovered on archaeomagnetic sites from France: Physics of the Earth and Planetary Interiors, v. 120, p. 111-136. https://doi.org/10.1016/S0031-9201(00)00148-5

Coe, R.S., Grommé, S., and Mankinen, E.A., 1978, Geomagnetic paleointensities from radiocarbon-dated lava flows on Hawaii and the question of the Pacific nondipole low: Journal of Geophysical Research, v. 83, no. B4, p. 1740-1756. https://doi.org/10.1029/JB083iB04p01740

Corona-Núñez, J., 1986, Tres Codices Michoacanos. Volumen preparado por el Centro de Estudios sobre la Cultura Nicolaita - Editado por la Universidad Michoacana San Nicolas Hidalgo - Morelia, Michoacán, México.

Cruz Rivera, S., 2019, La imagen del sonido en códices prehispánicos del centro de México: una propuesta metodológica. Pasado Abierto, v. 4, no. 9, p. 60-90. https://fh.mdp.edu.ar/revistas/index.php/pasadoabierto/article/view/3287/3491

De la Rea, A., and Escandón P., 1996, Crónica de la Orden De N. Seráfico P.S. Francisco, Provincia de S. Pedro Y S. Pablo de Mechoacán en la Nueva España (1639), Zamora, Michoacán: El Colegio de Michoacán, Gobierno del Estado de Michoacán, México.

Gómez-Mussenth, L.T., 2010, Análisis contextual para la interpretación de los petrograbados de las islas del Lago de Pátzcuaro. [Master's Thesis]: El Colegio de Michoacán A. C. Centro de Estudios Arqueológicos. Zamora, México.

González-Martínez, R., 2010, Alianza religiosa y realiza sagrada en el antiguo Michoacán: Revista Española de Antropología Americana, v. 41, no. 1, p. 75-96. https://doi.org/10.5209/rev_REAA.2011.v41.n1.4

Grove, D. C., 1973, Olmec Altars and Myth: Archaeology, v. 26, no. 2, p. 128-135.

Hernández-Quintero, E., Goguitchaichvili, A., García-Ruiz, R., Cervantes-Solano, M., and Nava, G.C., 2018 , Más de 100 años ininterrumpidos de registro geomagnético en México: implicaciones en la datación absoluta de algunos edificios históricos: Arqueología Iberoamericana, $v$. 39, p. 36-43. https://doi.org/10.5281/zenodo.3475444

Heyden, D., 1975, Los ritos de paso en las cuevas: Boletín del Instituto Nacional de Antropología e Historía, v. 2, no. 19, p. 17-26.

Heyden, D., 2005, Rites of passage and other ceremonial caves, in, Brady, J.E., and Prufer K.M., eds., In The Maw of the Earth Monster: Mesoamerican Ritual Cave Use, University of Texas Press, Austin, p. 21-34.

Lloyd, C. (compiler), 2016, Geologic formation of Cueva de la Huachizca, Michoacán, México.

Maldonado, B. and Rehren, T., 2009, Early copper smelting at Itziparátzico, Mexico: Journal of Archaeological Science, v. 36, no. 9, p. 19982006. https://doi.org/10.1016/j.jas.2009.05.019

Morales, J., Goguitchaichvili, A., Olay, A., Carvallo, C., and Reyes, B.A., 2015, Archeointensity investigation on pottery vestiges of puertas de rolón, capacha culture: in search for affinity with other Mesoamerican prehispanic cultures: Studia Geophysica et Geodaetica, v. 57 , p. 605-626. https://doi.org/10.1007/s11200-012-0878-z

Olmos, A.C., 2010, Los petrograbados de Tzintzuntzan, Michoacán: Un sistema de comunicación gráfica. [Master's tesis]: El Colegio de Michoacán A. C. Centro de Estudios Arqueológicos, Zamora, México.

Pavón-Carrasco, F.J., Rodríguez-González, J., Osete, M.L., and Torta, J.M., 2011, A Matlab tool for archaeomagnetic dating: Journal of Archaeological Science, v. 38, p. 408-419. https://doi.org/10.1016/j.jas.2010.09.021

Pavón-Carrasco, F.J., Osete, M.L., Torta, J.M., and De Santis, A., 2014, A geomagnetic field model for the Holocene based on archaeomagnetic and lava flow data: Earth Planetary Science Letters, v. 388C, p. 98-109. https://doi.org/10.1016/j.epsl.2013.11.046

Pollard, H.P., 1993, Tariacuri's Legacy: The Prehispanic Tarascan State: University of Oklahoma.

Pollard, H. P., 2008, A Model of the Emergence of the Tarascan State: Ancient Mesoamerica, v. 19, p. 217-230. https://doi.org/10.1017/ S0956536108000369

Punzo-Díaz, J.L., 2014, Los Antecedentes Pre-Hispánicos de Santa Clara del Cobre, in Santa Clara del Cobre, Zona de Monumentos Históricos: Instituto Nacional de Antropología e Historia, México, México D.F.

Punzo-Díaz, J.L., Castañón M., and González-González, L., 2015, Proyecto Arqueología y Paisaje del Área Centro-Sur de Michoacán Informe Técnico 2014-2015, Parcial temporada 2015: Archivo técnico del Instituto Nacional de Antropología e Historia, México, México D.F.

Punzo-Díaz, J.L., 2018, Paisaje y arquitectura en el mundo de los habitantes del Michoacán antiguo, in Sánchez-Nava, P., ed., Un patrimonio universal: las pirámides de México: Cosmovisión, cultura y ciencia, Instituto Nacional de Antropología e Historia, Gobierno del Estado de México.

Ramírez, F.,1959, Relación sobre la Resistencia de Michoacán en Pátzcuaro, in, Zubillaga, F., ed., Monumenta Mexicana, 1581-1585, v. 2, p. 474-538, Rome: n.p. (Original document was written in 1585).

Rissolo, D.A., 2001, Ancient Maya Cave Use in the Yalahau Region, Northern Quintana Roo, Mexico. [Ph.D. thesis]: University of California, Riverside. ProQuest Publishing. http://search.proquest.com/docview/250788855/.

Roskamp, H., 2005, La metalurgia prehispánica y colonial en Jicalán, Michoacán, México: una prospección arqueológica, A project report presented to the Foundation for the Advancement of Mesoamerican Studies, Project \#02011. http://www.famsi.org/reports/02011es/02011esRoskamp01.pdf.

Roskamp, H., 2010a, Gods of Metals: Tlatlauhqui Tezcatlipoca and the Sacred Symbolism of Metallurgy in Michoacán, West Mexico: Ancient Mesoamerica, v. 21, no. 1, p. 69-78. https://doi.org/10.1017/S0956536110000118

Roskamp, H., 2010b, The Nahuas of Tzintzuntzan-Huitzitzilan, Michoacán: History, Myth and Legitimization of a Prehispanic Señorío: Journal de la Société des Américanistes, v. 96-1, p. 75-106. https://doi.org/10.4000/jsa.11264

Thellier, E. and Thellier, O., 1959, Sur l'intensité du champ magnétique terrestre dans le passé historique et géologique: Annals of Géophysics, v. 15 , p. $285-376$.

Townsend, R. F., 1987, Coronation at Tenochtitlan, in, Boone, E.H., ed., The Aztec Templo Mayor: Dumbarton Oaks Research Library and Collection, Washington, D.C., p. 373-410.

Van Gennep, A., 1960, Les Rites de passage (1909), Chicago: University of Chicago Press.

Warren, J.B., 1990, Vocabulario en lengua de Mechuacán, Facsimile, Fuentes de la Lengua Tarasca óPurépecha, 2, Morelia: Filmax Publicistas, Morelia, Michoacán, Mexico. (Original document was written in 1559 by Maturino Gilberti.) 